УДК 655.3.022.11

\title{
ІЛЮСТРУВАННЯ ТА ОФОРМЛЕННЯ ВИДАНЬ КАЗКИ «БІЛОСНІЖКА ТА СЕМЕРО ГНОМІВ»
}

\author{
( М. В. Заблодський, магістрант, НТУУ «КПІ», \\ Київ, Україна
}

\section{Статья посвящена проблеме актуальности и технического совершенства оформления изданий сказки «Белоснежка и семь гномов». Проведен анализ уже существующих изда- ний этой сказки и выдвинуты предложения по их улучшению. \\ The article about the relevance and technical excellence of design publications fairy tale "Snow White and the Seven \\ Dwarfs". The analysis of the existing editions of this tale, and put forward suggestions for improvement.}

\section{Постановка проблеми}

Всі ми родом 3 дитинства. А яке дитинство без казок?.. Тому в кожному 3 нас живе ностальгія по казкам.

Людством створено безліч казок, а все ж таки ми ностальгуємо за Казкою, казкою з великої літери. Мабуть, вона у кожного своя; така,що пробуджує найглибші, найсвітліші спогади та почуття. Хтось захопився сюжетом, хтось одним з казкових героїв, але всі ми в дитинстві, перш за все, звертали увагу на малюнки на сторінках книжок. Траплялось, що закохувались в книжку ще до того, як її прочитали. В цьому велика сила мистецтва ілюстрації.

\section{Мета роботи}

На прикладі однієї з казок розглянути роль і значення ілюстрування та оформлення дитячих видань.

\section{Результати проведених досліджень}

Одна 3 найвідоміших казок «Білосніжка і семеро гномів».
Звичайно, її знають всі і різноманітних видань цієї казки дуже багато. Але мало хто знає реальну історію героїні казки.

Білосніжка (нім. Schneewittchen) - персонаж, відомий по казці братів Грімм. Білосніжка - красива дівчина, яку зла мачуха вигнала у ліс. Вона знайшла притулок у мешканців лісу - семи гномів (нім. Zwerge). Зла заздрісниця отруїла Білосніжку яблуком, але та воскресла від поцілунку прекрасного принца.

Казка братів Грімм про Білосніжку та гномів, як з'ясувалося, була заснована на реальних драматичних подіях. Прообразом Білосніжки послужила Марія Софія Маргарета Катерина фон Ерталь, яка народилася в замку Ерталь в сім'ї принца Філіпа Крістофа та Марії Єви фон Беттендорф. Досягнувши 14-річного віку, Марія Софія піддалася гонінням з боку своєї мачухи Клаудії Елізабетта фон Райхенштайн і якийсь час переховувалася від найманих убивць у відо- 
кремленій хатині місцевих рудокопів. Коли інтрига мачухи юної дівчини відкрилася, принц Філіп розлучився з нею, а Марія Софія повернулася у родове гніздо, де і дожила, так і не вийшовши заміж, до 70 років.

Крім цієї легенди популярна ще й інша. Вчені виявили паралелі між легендарною Білосніжкою та Маргаритою фон Вальдек. Маргарита мала неймовірну білу шкіру (як білий сніг) та була дуже вродливою. Як Білосніжка вона мала проблематичні відносини 3 мачухою. Маргарита виросла в шахтарському місті Вальдек, де маленькі діти, відомі як «карлики», працювали у шахтах. В 17 років Маргарита переїхала до Брюсселя. Там вона привернула увагу короля Філіппа II. Філіпп сподівався на ній одружуватися, але вона захворіла в результаті отруєння. Маргарита померла у віці 21 року. Драматична історія про молоду жінку захопила уяву людей і стала джерелом натхнення для казки.

Казки братів Грімм відомі й улюблені в усьому світі. Історія красуні Білосніжки, яку злість мачухи погубила, а любов прекрасного принца повернула до життя, ось уже двісті років хвилює серця дорослих і дітей. її переоформлювали, перевидавали сотні разів. Мабуть, в першу чергу, це зв'язано з особливостями цієї казки - цікавим сюжетом 3 гарним кінцем, таємнича атмосфера середньовіччя дають підставу для фантазії художника.

Звичайно, найбільшу роль в розвитку культури, особливо популяризації казок, грають книжки. Надзвичайно важливим є оформлення казок. Із великої кількості видань були вибрані найбільш вдалі, які якнайкраще передають суть і дух казки «Білосніжка».

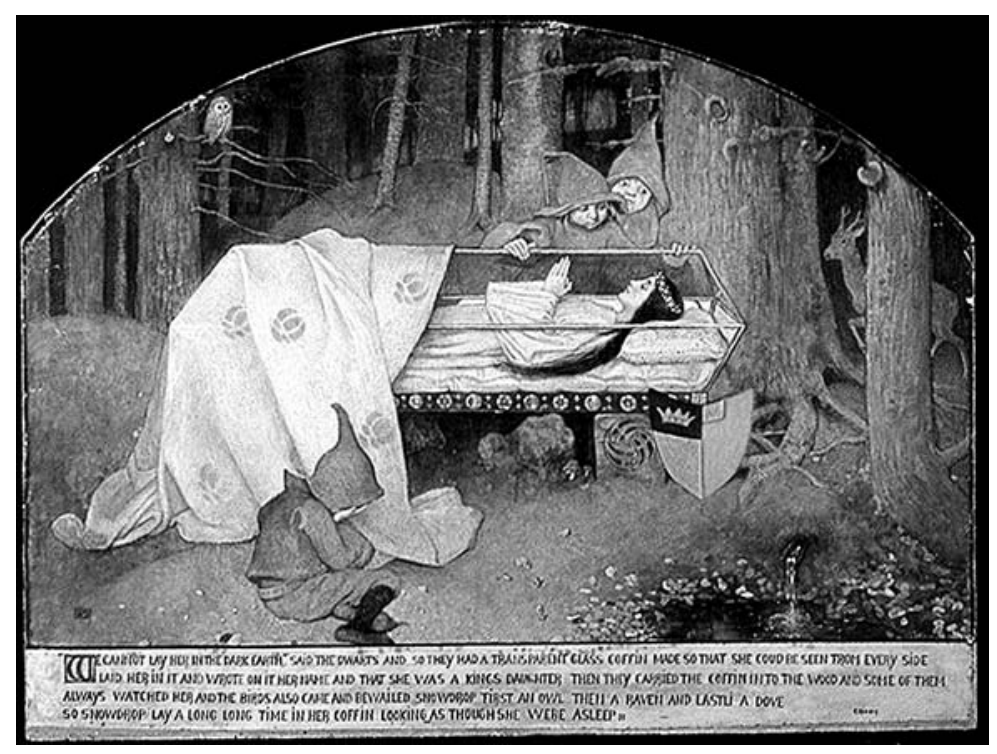

Рис. 1. М. Штокес. Гноми над померлою Білосніжкою 
Найперше ілюстрування казки було створено ще за часів Середньовіччя. Ці ілюстрації справжній давній манускрипт, автором яких є Маріанна Штокес (Німеччина).

Ще однією старовинною ілюстрацією до казки є робота Ганса Макарта. Він був справжнім академічним художником, в основному писав великі історичні та алегоричні картини та був культово відомим в 19 ст. Але навіть у нього $€$ картини, зв'язані з Білосніжкою. Його робота на цю тему - справжній витвір мистецтва, хоча й далека до дитячої книжки. На цій картині він передав момент, коли зла чаклунка пришла вбити Білосніжку.

Віденський живописець Ганс Макарт (1840-1884) найбільше прославився історичною картиною «Клеопатра». Ганс Макарт народився в епоху романтизму. Тому його вважали романтично спрямованої особистістю, що дарує глядачам ліричний настрій. Емоційна піднесеність його робіт підкуповувала відвідувачів художніх галерей.

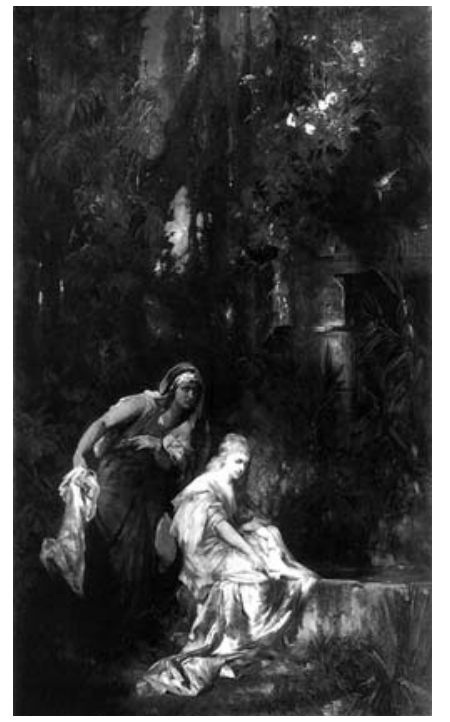

Рис. 2. Г. Макарт. Білосніжка

Одним із самих відомих видань казки про Білосніжку за часів СРСР є варіант Південно-Уральського видавництва (1978 рік). Гарна композиція та стилізація.

Можливо, це видання сьогодні не назвеш найбільш вдалим та красивим, але воно було досить популярне в часи СРСР. В ньому теж ілюстрації гарно передають образи героїв і атмосферу казки.

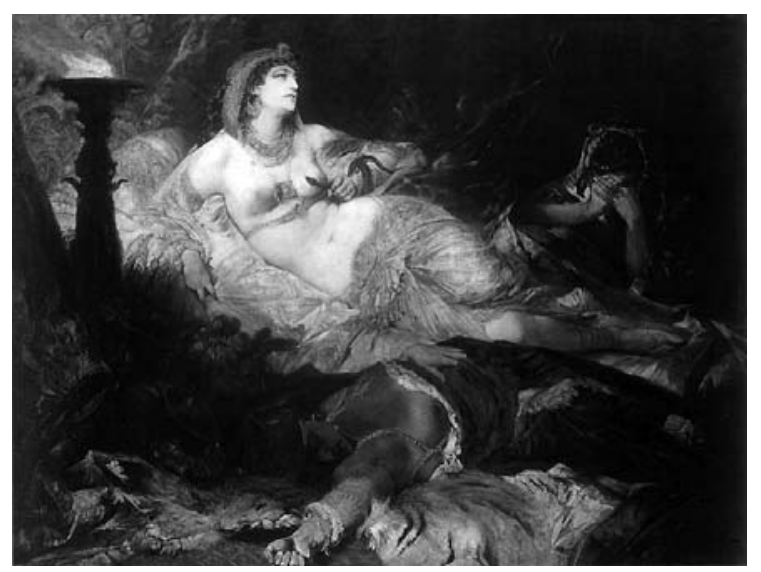

Рис. 3. Г. Макарт. Клеопатра 


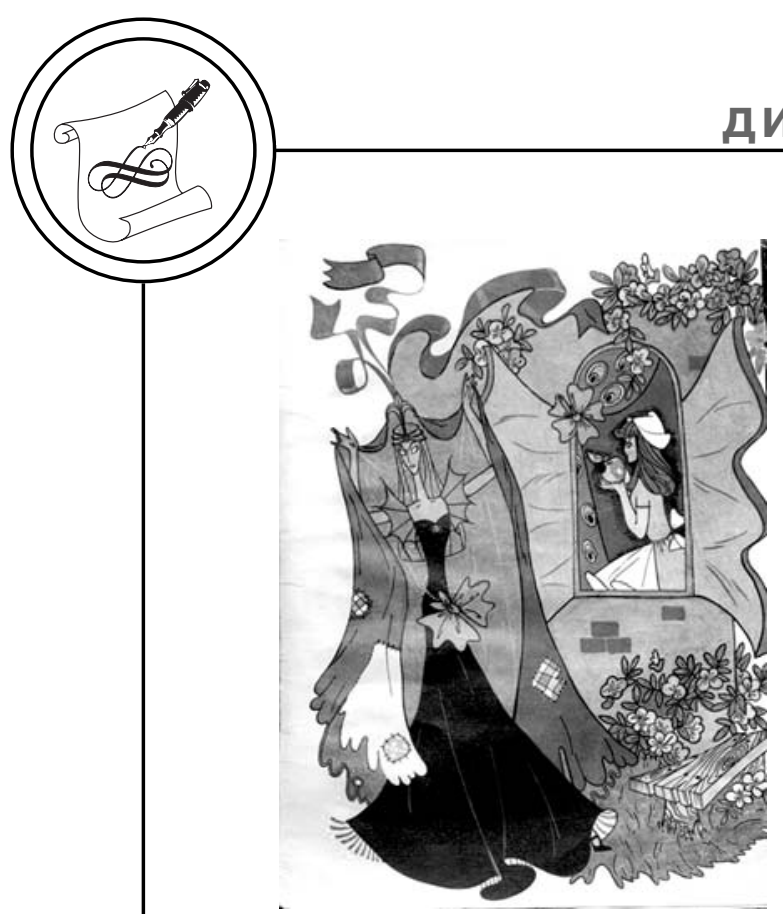

Рис. 4. «Білосніжка» ПівденноУральського в-ва

Викривлені дерева, павутиння, чиїсь очі, що світяться вночі все це чудово передає жах покинутої в лісі дівчинки. Автор дуже гарно зберігає єдину декоративну інтерпретацію зображень на всіх ілюстраціях, чітко передає настрій персонажів.

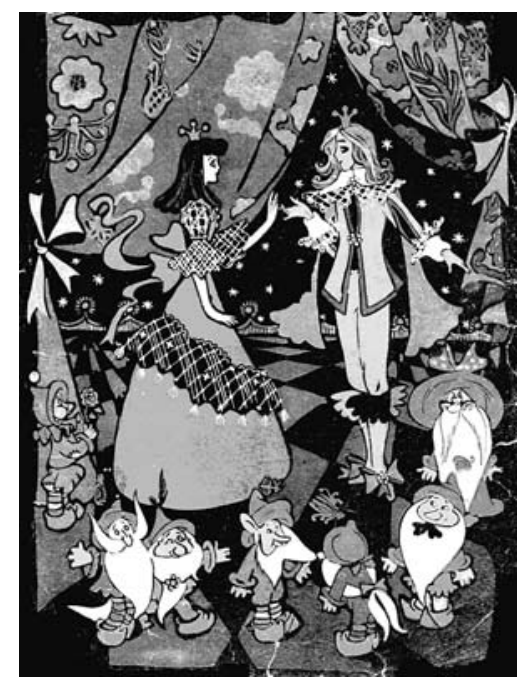

Рис. 6. «Білосніжка» ПівденноУральського в-ва

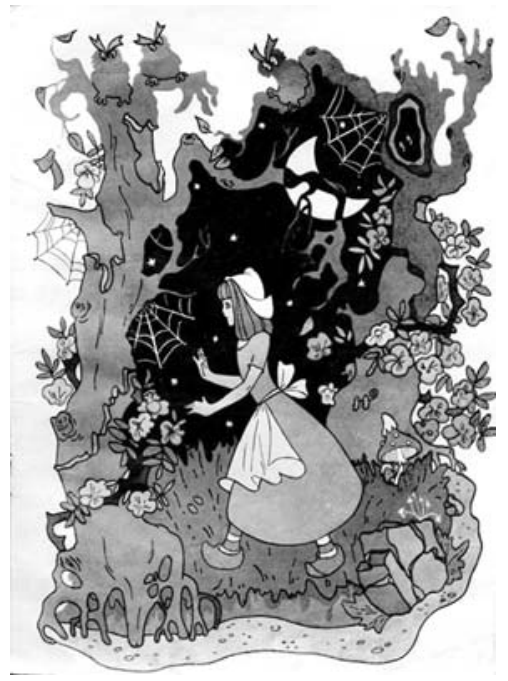

Рис. 5. «Білосніжка» ПівденноУральського в-ва

Одним 3 найкращих видань казки вважається видання «АБА-БА-ГА-ЛА-МА-ГИ» (переказ Івана Малковича за перекладом Віталія Коротича, ілюстрації Оксани Ігнащенко). Це видання отримало міжнародне визнання та багато премій. Але, якщо проаналізувати, в ньому $є$ чимало недоліків. Найбільший - погано продумана обкладинка. Вона не привертає до себе уваги; окремі деталі (особливо замок на задньому плані) вражають своєю примітивністю. Також в ній абсолютно відсутня атмосфера казки. Але, не дивлячись на це, в обкладинці $€$ певна динаміка (особливо завдяки сходам та перспективі). Крім того, присутній цікавий хід з назвою на ній гармонійно вписані 7 гномиків.

Звертають увагу і гарно продумані ілюстрації - красиві, досить деталізовані; чудові композиції - ілюстрації наче огортають текст. 
Інше оформлення казки у видавництва «Пегас» (Харків; художники - Квітка О. Л. та Варавін С. В.). Вишукане видання гарно продумана обкладинка, красивий форзац (кольоровий квітковий орнамент на червоному фоні). Але невдало побудований титул - не виразна, не гармонійна композиція та занадто простий шрифт для заголовку. Верстка тексту невдала.

Російське видання «Белоснежка» (із циклу “Сказки» Братьев Гримм, художники Н. Цейтин та М. Шлюсберг) цікаве, але привертають увагу лише великі поля та велика буквиця. Гарний хід - буква привертає увагу, поля створюють більший простір і полегшують читання. Ілюстрації аквареллю, повністю відповідають змісту, але занадто спрощені, без будьякої вишуканості та погано закомпоновані.

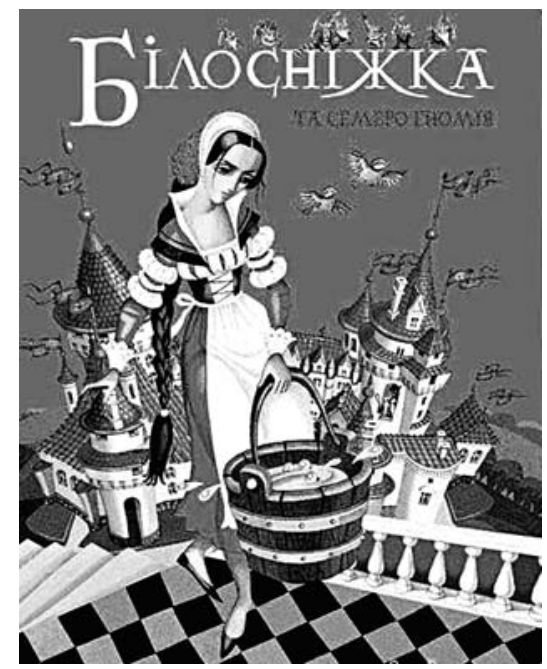

Рис. 7. О. Ігнащенко. Білосніжка (обкладинка)

Розглянемо оформлення казки видавництвом «Лабіринт» (Київ, 2009 рік, автор ілюстрацій невідомий).

Це вдале оформлення дитячої книжки - великий шрифт, багато ілюстрацій, які трохи відрізняються від традиційного «діснеївського» стилю. Радує

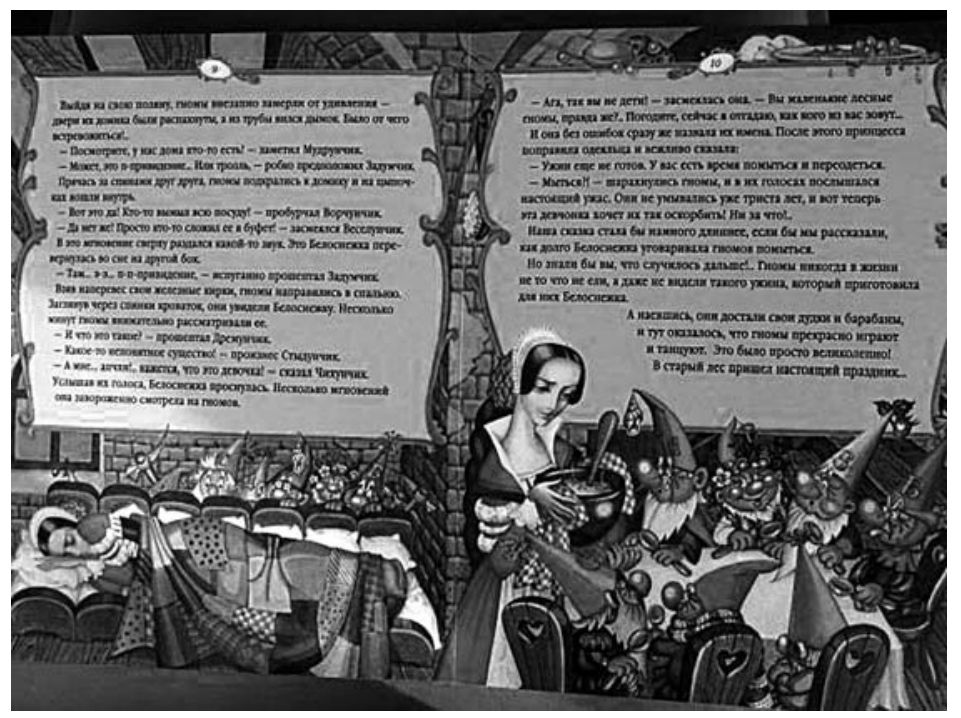

Рис. 8. О. Ігнащенко. Білосніжка (розворот) 


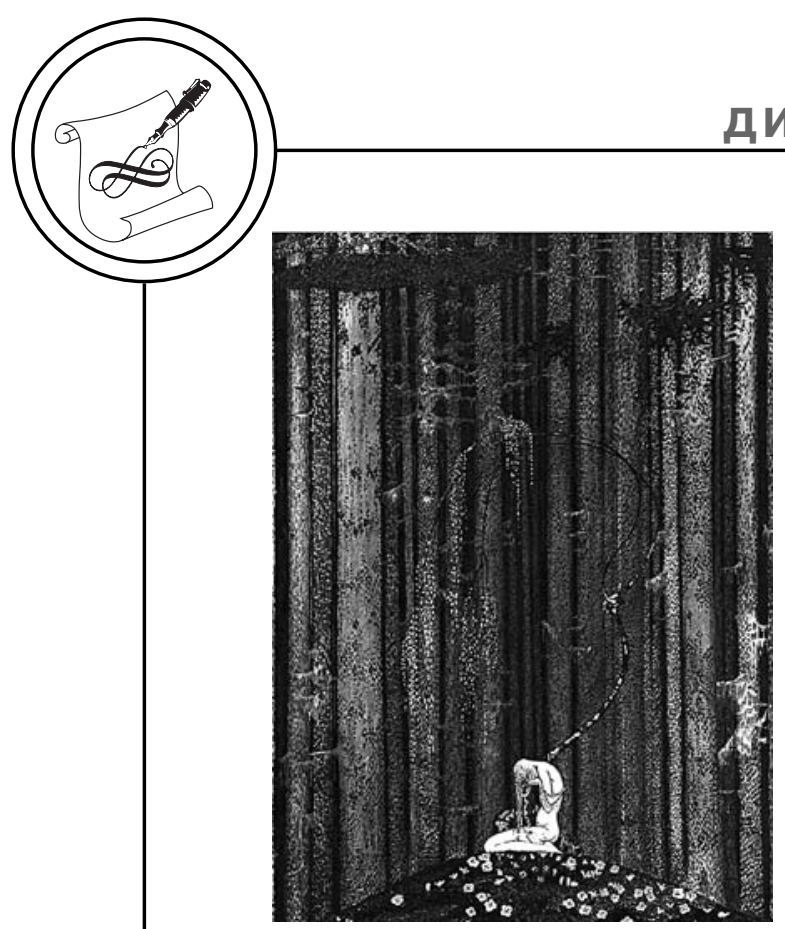

Рис. 9. «Білосніжка» в-ва «Лабіринт»

чудове оформлення - цілі хороводи гномів і забавних звіряток, які дитина може роздивлятися годинами.

Ще одним чудовим виданням $€$ книжка видавництва «Азбука»

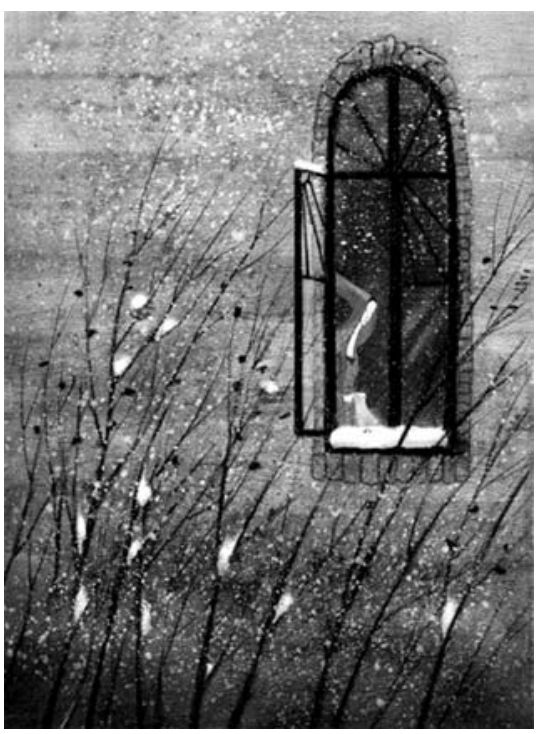

Рис. 11. М. Міхальська. Білосніжка

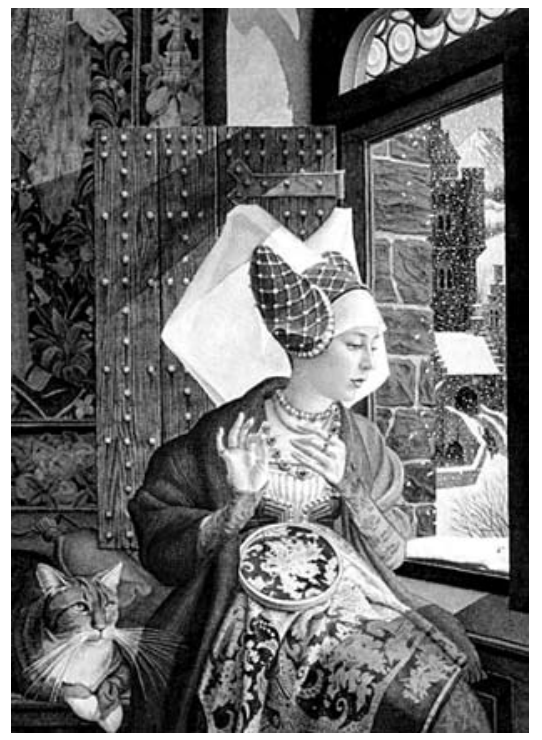

Рис. 10. М. Федоров. Білосніжка

(Київ, 2010 рік, Серія: Казка в подарунок). Стильні і барвисті ілюстрації Михайла Миколайовича Федорова надають цій книзі особливу чарівність. Михайло Миколайович - член Спілки художників, постійний учасник престижних виставок в Росії і Європі, номінант конкурсу «Мистецтво книги» в Москві і бієнале у Варшаві.

Великі гарні ілюстрації вишукано декоративно інтерпретовані, зроблені під старовину.

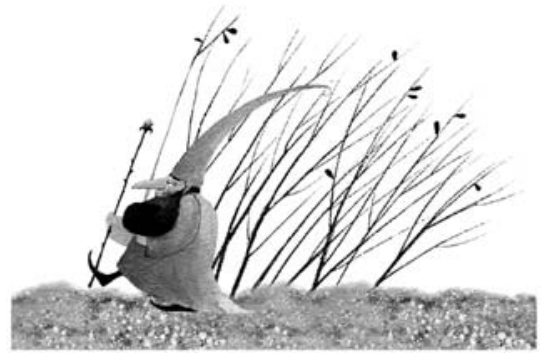

Рис. 12. М. Міхальська. Гном 


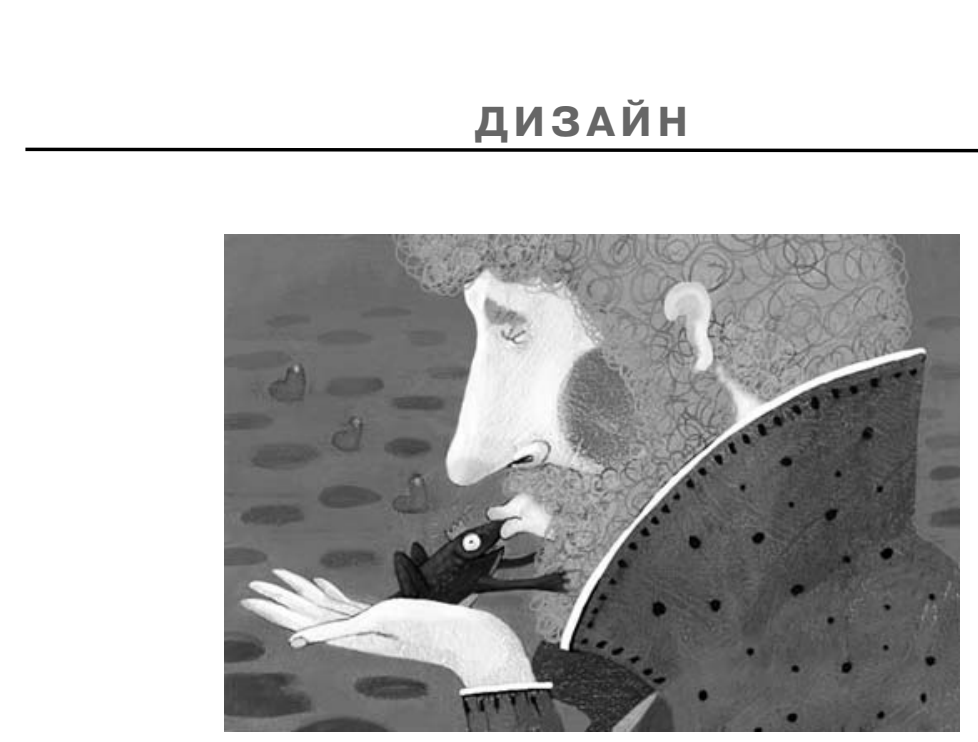

Рис. 13. М. Міхальська. Царівна-жаба

Папір білий, шрифт досить великий. Книжка відповідає типу подарункового видання.

Особливої уваги заслуговують ілюстрації Марії Міхальскої (Москва, 2009 р.) Вони дуже прості за виконанням та сюжетом, але настільки спрощені та акварельні - ідеальний приклад ілюстрацій до дитячих книжок, особливо для дошкільнят.

Марія Міхальска - молодий російський ілюстратор. У 2007 закінчила МГУП, Факультет Графічних Мистецтв. Член Мос-

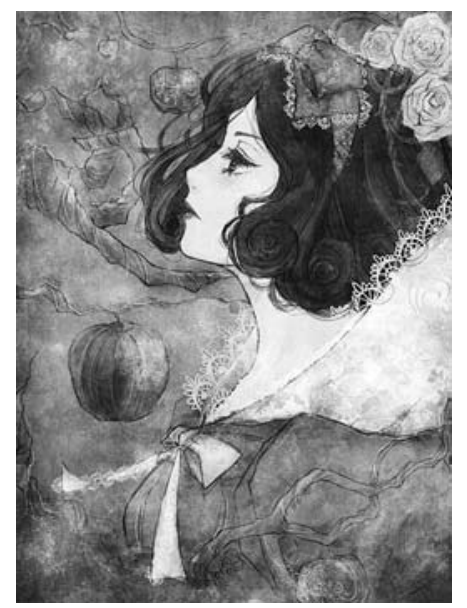

Рис. 14. Ш. Санторе. Білосніжка ковського Союзу Художників, відділення книжкової графіки. Учасник і призер міжнародних і російських конкурсів.

Також існують ілюстрації до Білосніжки в стилі манго. Автор - Шарль Санторе (Франція). В ілюстрації повністю відсутній сюжет, будь-яка динаміка, але скільки ж в ній вишуканості!

Наступна ілюстрація $є$ роботою також відомого французького ілюстратора - Бенджаміна Лакомбе. Бенджамін створив до казки «Білосніжка» не просто ілюстрації, а справжне типографське диво - всі ілюстрації тривимірні. Крім того, старанно промальована кожна деталь, цікавий сюжет і приємні теплі кольори.

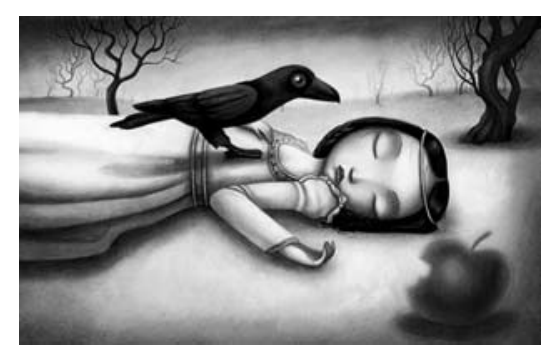

Рис. 15. Б. Лакомбе. Білосніжка 


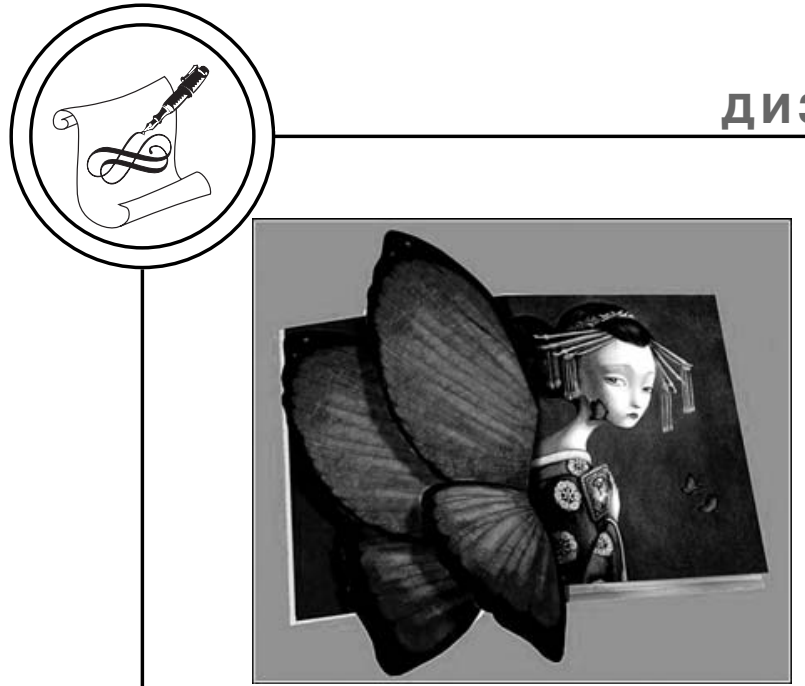

Рис. 16. Б. Лакомбе. Дівчинаметелик

У дитинстві Бенджамін хотів бути аніматором, захоплюючись мультфільмами від Тіма Бертона та студії Уолта Діснея. Не важко передбачити, що відчують діти, до яких потрапить книжка від Бенджаміна Лакомба. Він звів створення тривимірних книг, по суті, в мистецтво. Адже в дитячих книжках, зазвичай, головне - не текст, а візуалізація.
Як це не дивно, але найбільш живим та відомим циклом ілюстрацій до казки можна назвати анімацію «Білосніжка і сім гномів», створену у 1937 році студією Уолта Діснея. Це був перший повнометражний мультфільм у повному кольорі. Крім того, студія Діснея випустила ціле видання казки «Білосніжка та семеро гномів». Воно якнайкраще розкриває зміст, суть казки. Саме завдяки гарно продуманому сюжету, характерним типажам героїв, чудовій кольоровій гамі анімація та книжка, ілюстрована «під анімацію», завоювали весь світ і залишаються популярними до сих пір.

\section{Висновки}

Художники, які ілюструють дитячі книжки, мають дотримуватись певних правил і рекомендацій:

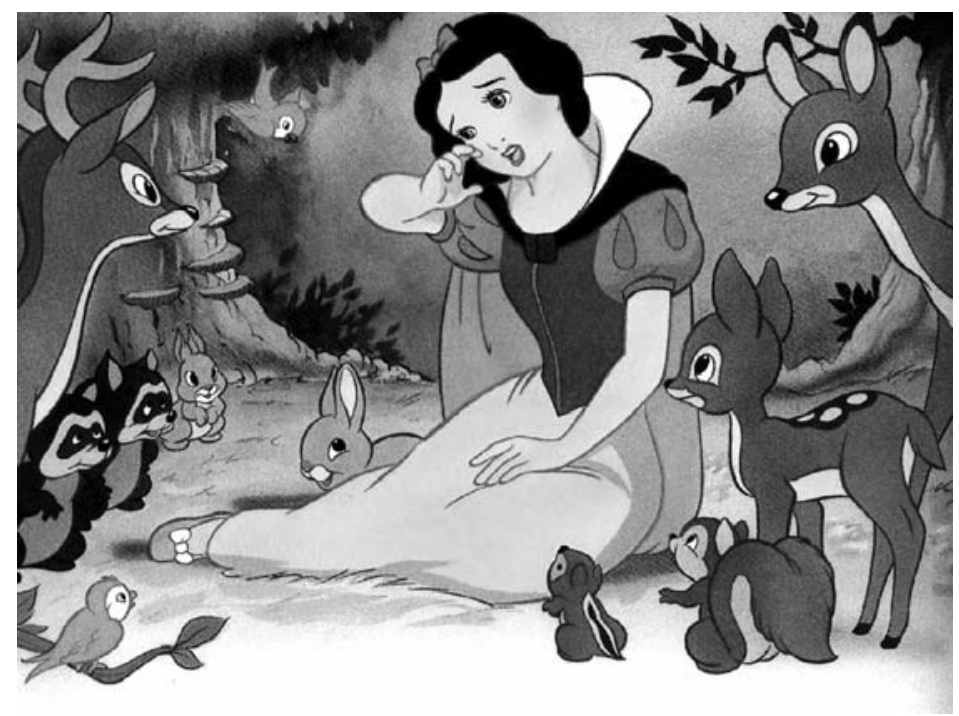

Рис. 17. Студія У. Діснея. Білосніжка та сім гномів 
1. Дитяча книжка має бути яскравою, святковою, навіть розкішною.

2. Якість паперу, його фактура, колір теж мають велике значення для дитини. Сторінки книжки має бути приємно перегортати. Колір має бути теплим, яскравий білий - занадто важкий фактурний колір. Найменш важкими і в той же час змістовними є кольори акварелі, яка не важка і не достатньо яскрава. Це, так званий, лесирувальний колір.

3. Дитина до 10 років, яка читає книжку, не тільки і не стільки іï читає, а розглядає і грається з буквами і з зображеннями. Тому потрібні рухливопобудовані сторінки й розвороти. Розворот може вважатись як ціле і вважатись цілісним полем дій, тим самим зменшуючи значення правої сторінки. Велике значення мають розмір книги, її формат. Великі розміри і товщина книги справляють на дитину велике враження.

4. Щодо пропорцій, то тут можна говорити про досить ши- рокий, горизонтальний форзац, який може бути дещо вужчим за квадрат.

5. Відносно шрифту вимог небагато - дітям подобаються букви з жирним чорним штабом. Важливу роль відіграють заглавні літери. Чорний колір в ілюстраціях дітям дошкільного віку не подобається, але в букві чорний сприймається як її колір і надає букві певну конкретність. Тому в дитячій книзі шрифту треба дозволяти турбуватись про рівне поле стовпця й текучості рядка, про характеристику кожної букви. Кольорова просторовість шрифту, що походить з різного навантаження кольором вертикалі й горизонталі штамба й гілок, доступна дитячому розумінню.

Найсуттєвішу частину дитячої книги складає ілюстрація. На цьому пункті я досить ґрунтовно зупинявся на початку статті. Дотримуючись запропонованих критеріїв, було вибрано найбільш вдалі видання «Білосніжки»: А-БА-БА-ГА-ЛА-МА-ГИ, Пегаса, Азбука.

1. Бенжамин Лакомбом и его трехмерные книжки. - Париж, 2009. - 20 с. 2. В. Фаворский. Художники детской книги о себе и об искусстве / В. Фаворский. - М., 1972. - 200 с. 3. Білосніжка та семеро гномів. - К. : А-БАБА-ГА-ЛА-МА-ГА, 2006. - 30 с. 4. В. И. Ляхов. Теоретические проблемы искусства книги / В. И. Ляхов. - М. : Детская книга, 1969. - 300 с.

$$
\begin{array}{r}
\text { Рецензент - Б. В. Валуєнко, к.мист., } \\
\text { професор, НТУУ «КПІ» }
\end{array}
$$

